«Keruen» scientific journal

M.O.Auezov Institute of Literature and Art

ISSN 2078-8134

Volume 3, Number 68 (2020)

https://doi.org/10.53871/2078-8134.2020.3-03

МРНТИ 17.07.29

\author{
М. Яхьяпур \\ Тегеранский университет, Иран \\ E-mail: myahya@ut.ac.ir \\ ORCID iD: 0000-0001-8195-6909

\section{ПАТРИОТИЧЕСКИЕ И ГЕРОИЧЕСКИЕ МОТИВЫ В ПОЭЗИИ АЛЕКСАНДРА ТВАРДОВСКОГО И КЕЙСАРА АМИНПУРА}

Аннотация. Литературные связи и взаимодействия проявляются в мировом литературном процессе как напрямую, так и опосредованно. Данная статья посвящена литературным параллелям в поэтическом творчестве известного русского поэта, участника Великой Отечественной войны, главного редактора литературного журнала «Новый мир» Александра Твардовского и популярного современного иранского поэта Кейсара Аминпура. Проблемы войны и мира - вечные проблемы национальных литератур на протяжении ряда веков. Они находят отражение в жизни, судьбе и творчестве русского поэта. Проходят как ведущие и в поэзии К. Аминпура. Тоска по Родине, мечта о том, чтобы прекратились военные действия и был мир на земле - общие концепты поэзии А. Твардовского и К. Аминпура. Людские судьбы втянуты в водоворот событий, но необходимо бороться за мир. Патриотические и героические мотивы в произведениях русского и иранского поэта и способы их отражения в стиле, языке, композиции произведений имеют отличие, что обусловлено спецификой развития литературного процесса в СССР в XX веке и в Иране последней четверти XX века и первого десятилетия XXI столетия. В то же время есть общее, что позволяет сравнивать поэтическое творчество А. Твардовского и К. Аминпура. Мотивы патриотизма и героики анализируются в контексте темы природы. Концепт Родина и пейзажи малой Родины в поэзии нераздельны.

Ключевые слова: патриотическая лирика, художественный перевод, героика, культура, мотив, стиль, поэма, пейзаж, эпитет, метафора.

Вступление. Классики русской литературы проявляли глубокий интерес к Востоку, изучали его, передавали через свои тексты, своих героев уважительное отношение к странам и людям исламской культуры. Творчество Фирдоуси, Хафиза, Саади и других популярно в России. Художественные переводы произведений выдающихся поэтов - мыслителей Востока постоянно переиздаются по причине того, что их авторы ставят важные вопросы и проблемы, обращаясь с ними ко всему миру. Наша студенческая молодежь изучает важные темы мировой цивилизации, проводит анализ художественных текстов, изучает документы, дневники, другие источники. Таким образом происходит изучение и проникновение в культуру другой страны, и это способствует сближению наших народов.

Интересным, на наш взгляд, является сравнение ведущих мотивов в поэтическом творчестве А. Твардовского и К. Аминпура. Тема войны и мира отражена в их художественных текстах.

Методы. Нами избрана методика сравнительно-сопоставительного изучения поэм и стихотворений А. Твардовского и К. Аминпура, которая позволит выявить главное и прийти к значимым литературоведческим выводам.

Результаты. В Иране всегда было уважительное отношение к России, русской культуре в целом. Интерес к изучению на университетском уровне русского языка и русской 
литературы существенно вырос за последние годы. Сказывается в целом активизация отношений между Ираном и Россией. Изданная в 2010 году антология иранского рассказа «Современная иранская проза» еще более укрепила литературный и издательский диалог.

Патриотические и героические мотивы являются не только приоритетом тематики современных литератур разных стран мира. Они отражены в фольклоре и устной литературе народов многих стран. Тема героизма, любви к малой Родине и сыновнее чувство долга перед страной объединяют поэтическое искусство А. Твардовского и К. Аминпура. Главные редакторы ведущих литературных изданий России и Ирана, А. Твардовский и К. Аминпур создали свой поэтический мир, в котором лирические герои поэм и стихотворений волнуются за судьбу и будущее своей Родины.

А. Твардовский защищал Родину в годы Великой Отечественной войны. К. Аминпур был участником военных событий 1978-1979 годов. Поэты от призыва к защите Родины переходят к проблемам мира и свободы. Художественный стиль русского и иранского поэта основан на языковых выразительных средствах: эпитетах, метафоре, гиперболах, олицетворении, аллитерации и т.д. К. Аминпур, автор поэтических сборников, является также издателем и ученым. Ведущие темы его поэтического творчества - защита Родины, воспитание чувства патриотизма и ответственности за страну.

Обсуждение. Современное научное познание, «отмеченное универсализацией объектов исследования, интеграцией наук, трансформацией методов изучения, с одной стороны, является объективным показателем сегодняшней научной картины мира, с другой своеобразным сигналом, предостерегающим от размывания границ науки, утраты специфических задач и категориального аппарата» (Бралина, 2007: 3). Выдающийся русский поэт XX века А.Т. Твардовский с первых и до последних дней Великой Отечественной войны был ее активным участником и делал все, что требовалось для фронта. Поэт, журналист часто выступал в армейской и фронтовой печати, писал очерки, стихотворения, фельетоны, лозунги, листовки, песни, статьи, заметки (Бердяева, 1989: 157).

После войны, помимо основной литературной работы, А. Твардовский возглавляет литературный журнал «Новый мир», на страницах которого публиковались интересные, содержательные и остро актуальные произведения. Позиция главного редактора авторитетного литературного издания СССР всегда была принципиальной и объективной.

В военной поэзии А. Твардовский передает чувство исполненного перед Родиной долга. В стихотворении «Я убит подо Ржевом» лирический герой уверен в том, что «недаром боролись / Мы за Родину мать (Твардовский, 2003: 54). «Архетип Родины, родного дома продолжает оставаться определяющим в современной прозе» (A. Afanasyeva, A. Zhaksylykov A., N. Sarsekeeva, 2016: 688). В разных стилевых решениях концепт малой Родины Смоленщины раскрыт А. Твардовским и К. Аминпуром, который пишет о родном Иране.

Память о каждом павшем на полях Великой Отечественной войны звучит в поэзии А. Твардовского:

Я знаю, никакой моей вины

В том, что другие не пришли с войны,

В том, что они - кто старше, кто моложе -

Остались там, и не о том же речь,

Что я их мог, но не сумел сберечь, -

Речь не о том, но все же, все же, все же... (Твардовский, 2003: 49).

Революционная и военная тематика стала ведущей в поэзии К. Амин- пура, на творчество которого повлияли иранская революция 1978-1979 годов и война 1980 года. Поэт пишет о страдании и горе жителей своего родного города в период военных действий. Его стихам присущи «камерность, лиричность в изложении» (Тари, 2015: 379), «высокий патриотизм, накал, героический пафос» (Тари, 2015: 380).

В современной литературоведческой науке получает широкое распространение теория о том, что даже самое национальное явление является сложнейшим сплавом разных культур 
и взаимовлияний. А. Твардовский участвовал в сражениях Великой Отечественной войны, работал военным корреспондентом на фронте. Он передает поэтическими средствами психологическое настроение солдат. Вершиной военной поэзии А. Твардовского является поэма «Василий Тёркин». «Книга про бойца» - поэтическое утверждение народного единства. Поэма А. Твардовского - «героическая эпопея, с отвечающей эпическому жанру объективностью, но пронизанная живым авторским чувством, своеобразная во всех отношениях, уникальная книга, вместе с тем развивающая традиции реалистической литературы и народно-поэтического творчества» (Кормилов, 1998: 284).

Осмысливая термин «автор произведения», Н. Смирнова разделяет «реального автора произведения, «образ автора» и «автора» как субъекта творческой активности (обнаруживающейся в построении произведения)» (Смирнова, 2001: 377). Автор поэмы «Василий Теркин», выстраивая своеобразно композицию художественного произведения, в котором каждая глава, по сути, самостоятельна, любит своего героя, любит свою Родину Смоленщину. Образ автора возникает за скупыми строками повествования. В то же время в тексте поэмы, язык которой близок к народному поэтическому языку, широко представлены эпитеты, метафоры, гиперболы, олицетворение, аллитерация и т.д.

Таким образом, А. Твардовский как автор, творец поэмы «Василий Теркин» выступает «как реальное лицо с определенной судьбой, биографией, комплексом индивидуальных черт. Во-вторых, это образ автора, локализованный в художественном тексте, т.е. изображение писателем, живописцем, скульптором, режиссером самого себя» (Хализев, 1999: 54). Втретьих, это художник-творец, имманентный произведению, субъект художественной деятельности.

Постоянный член Академии персидского языка и литературы К. Аминпур занимается поэзией на протяжении четверти века, свободно размышляя о сложных проблемах современности (Салахшур, 2010: 85). На формирование его поэтических взглядов повлияли последователи поэтической школы Нимо. К. Аминпур стал одним из современных и популярных поэтов. Его поэзия проста, ясна и общедоступна, покоряет оригинальностью поэтического мышления и новизной содержания стихотворений и поэм.

В то же время он известен и как ученый, создатель актуальных и новаторских научных исследований в области культуры и литературы древнего и современного Ирана. К. Аминпур родился в Дезфуле, на юго-западе Ирана, в 1959 году. С 1981-го по 1997 годы занимал должность редактора журнала «Соруш». С 1988-го по 2004 годы - редактор литературнохудожественного журнала «Сорушэ ноджаван».

Своё присутствие в художественной литературе Ирана он увековечил двумя поэтическими сборниками. Первый «В аллее солнца» состоит из двустиший и рубаи. Второй сборник «Дыхание утра» включает оды и новые жанры поэзии современной литературы (нимаи). Сборники увидели свет на протяжении нескольких месяцев 1984 года и с самого начала привлекли внимание поэтов и любителей поэзии. Поэтическая откровенность стала основной предпосылкой для установления прочной связи с читателями, как, например, в «Стихотворении для войны».

В анализируемом стихотворении поэт говорит о необходимости мира во всём мире. Он не равнодушен к важнейшим проблемам времени. Переживания лирического героя выражены открыто. «Стихотворение для войны» передает чувства жителей Ирана в период военных действий. Автор произведения восхищен их героизмом, терпением и мужеством. Поэтическое слово настолько убедительно, что чувства горя и ненависти передаются читателям, овладевают их сердцами. (В дальнейшем стихотворения К. Амнипура даются на русском языке в моем переводе. - М.Я.).

Ведущий лейтмотив - необходимость защиты родины, воспитание чувства ответственности за страну. Сочувствие пострадавшим мирным жителям Ирана, подвергшимся нападению беспощадного врага, призывает автора не только писать о войне, но и эффективно с ней бороться. Картины последствий ракетных ударов, под которыми оказываются беззащитные женщины и дети, впечатляют читателя. 
Я хотел сочинить стихи для войны

ميخو استم شعرى بر ای جنى بكويم

Не смог

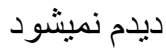

Языку нельзя говорить о сердце

ديكر قلم زبان دلم نيست

Сказал я: надо бросить карандаши

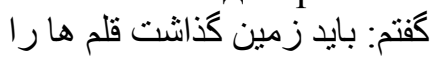

Слово как холодное оружие

ديكر سلاح سرد سخن كارساز نيست

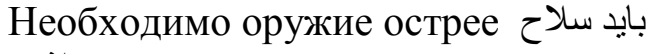

تيز ترى برداشت

(Аминпур, 1990: 22).

Война всегда имеет двух рассказчиков-повествователей: народ и государственные средства массовой информации. Военная поэзия К. Аминпура - новый критический и возрожденный эпос. Рассказывая о страданиях жителей страны, поэт обращается к эпическим темам. Его слова для своих соотечественников - это слова, извещающие о страшном событии. «Стихотворение для войны» К. Аминпура передает чувства иранцев во время военных событий и призывает любить и защищать родную землю, потому что «человек занимает в мире совершенно особое положение, являясь одновременно и обладателем времени, будучи сам его частью, и покорителем пространства» (Квантре, 2013: 101).

Природа военной поэзии А. Твардовского никогда не оставляет поэта равнодушной:

Как после мартовских метелей,

Свежи, прозрачны и легки,

В апреле

Вдруг порозовели

По-вербному березняки... (Твардовский, 2003: 54).

В творчестве современного иранского поэта сильны традиции персидской поэзии с образами-символами тюльпана, горы и т.д. Природа способствует раскрытию внутреннего мира персонажей. Он уподобляет павших на войне тюльпанам, потому что в иранской культуре тюльпан является символом крови мучеников. Поэт поэтизирует слёзы, представляя их одним из способов уничтожения горя, памяти о горе и насилии:

Давай зайдем к тюльпанам

بيا باه خانه ى آلاله ها سرى بزنى

Своему сердцу говорим о другом горе

مينزب يركيد فرح دوخ لد اب غادز

Можно небо омыть слёзами?

مينزب يركيد فرح دوخ لد اب غادز

Украшаем кровью землю цветов

مينزب يركيد كنر نيمز يورب نوخز

(Аминпур, 1990: 34).

Персонажи в лирике К. Аминпура нередко сравниваются с яркими природными явлениями, цветами, листьями, деревьями, горами и т.д.

Упал он так, 
داتفا

Как падает жёлтый лист,

دتفايمدرزقافتانآكر بهكناسناً

Как смерть холодной катастрофой падает,

دتفايمدرسقافتانآكر مهكناسنآ

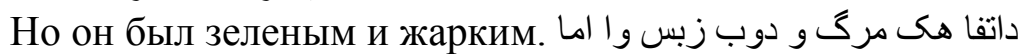

داتفاهكر تودوبزبسو الما

(Аминпур, 1996: 39).

Стихотворения К. Аминпура Махдия Тари сравнивает с поэзией Анны Ахматовой, «акцентируя внимание на гендерном аспекте» (Тари, 2015: 380) на примере поэтических сборников российской поэтессы. Было бы интересно сравнить поэзию К. Аминпура с поэтическим творчеством казахстанского поэта В. Михайлова, «в сердце которого навылет «родина сквозит / потусторонним или свежим дымом»... Стихотворения строятся по типу контраста... Они музыкальны, ритмичны» (Ананьева, 2015: 66). Большое место в стихотворениях и поэмах русского поэта Казахстана занимает пейзаж. «Звездный мотив и Млечный путь являются сквозными в творчестве В. Михайлова, неповторимого мастера пейзажных зарисовок» (Ананьева, 2015: 65).

Современные исследователи поэтических сборников К. Аминпура прослеживают эволюцию его поэтического мастерства от форм газелей, касыда, рубаи, двустиший, маснави в первые годы после Исламской революции к свободному стиху. Описание картин природы К. Аминпуром можно сопоставить с пейзажными зарисовками Сохраба Сепехри, у которого природа - символ вечности и бесконечности. Художественный мир С. Сепехри «раскрывается через ассоциации с жизнью природы. Именно отсюда стремление к всеобщей гармонии, единству всего сущего на земле» (Яхьяпур, Карими-Мотаххар, Мохаммади, 2012: 186).

В «Стихотворении для войны» К. Аминпура лирический герой словно беседует со звездами, которые предостерегают его:

Звезды говорили о плохой ночи...

دنتفى يم بش دب ز ا ناكر اتس

(Аминпур, 1990: 22).

И в то же время автор-повествователь предупреждает лирического персонажа:

Здесь нельзя доверять звездам

تسين يدامتعا جِيه ار ناكر اتس

(Аминпур, 1990: 22).

Свободный стих дает более возможностей для разнообразной манеры письма.

Тема Родины, занимающая значительное место в поэзии современного иранского автора, проявляется прямо или косвенно, через поэтические ассоциации. Воспевание красоты родины - важнейший лейтмотив в творчестве поэта.

Незаметный план в моей памяти -

زونه مداى رد تسا يكنرمك حرط

напомню о красивой равнине...

من باه ياد دشت آبادم هنوز

(Аминпур, 1990: 48).

Чувства лирического героя сопоставимы по силе с горами Ирана:

Печаль моя плотнее склона горы Алванда 
اندوه من انبوه تر از دامن الوند

Гордость моя более торжественна, чем горы Дамаванда

شكوه تر از كوه دماوند غرورم

(Аминпур, 1990: 54).

Выводы. В современном мире продолжаются военные столкновения, локальные войны, но голос писателя и поэта может предостеречь от масштабных катаклизмов, потрясений и последствий. Лирика воспитывает любовь к Родине, чувство патриотизма, что было исследовано в данной статье на примере творчества А. Твардовского и К. Аминпура. Русский и иранский поэты раскрывают военные проблемы простым, понятным читателю стилем, без приукрашиваний и усложненных поэтических конструкций. Простой и ясный поэтический язык делает их творчество понятным и общедоступным. К. Аминпур и А. Твардовский воспринимают войну как всенародное бедствие, угрозу жизни и чести человека, тяжкое испытание, избавление от которого связано с великим, всенародным трудом, поэтому война у них - работа, ежедневная и героическая. Каждый из них представляет в то же время свою поэтическую школу.

А. Твардовский пришел в литературу не только с милитаристской тематикой, с произведениями о Великой Отечественной войне. Его привлекала крестьянская жизнь, политика, а военная тематика появилась позже, с началом Великой Отечественной войны. В отличие от К. Аминпура А. Твардовский в поэме «Василий Теркин» использует фольклорные песни, частушки, пословицы и поговорки: «Я от скуки мастер на все руки», «Делу время - час забаве» и.т.д. Разговорный язык придает поэме особо доверительное звучание. Автор словно беседует с каждым из читателей, а сама поэма легко распадается на отдельные самостоятельные главы, легко запоминающиеся наизусть.

В настоящее время в десяти университетах Ирана преподают русский язык и литературу, растет число желающих изучать русский язык, который становится более привлекательным для иранских студентов, несмотря на его сложность. Изучая русскую литературу, выявляя параллели в ее развитии с иранской литературой, студенты и молодежь успешнее осваивают русский язык и русскую культуру. В процессе постижения языка происходит взаимодействие двух типов сознания, которые открываются друг другу. При этом происходит не только познание друг друга, но и самопознание через погружение в другой культурный мир. Литературный процесс мы изучаем как часть общественной жизни, в которой происходят сложные процессы. Например, современный писатель Сергей Лукьяненко дает нам возможность пережить вместе со своими героями исход борьбы светлого и темного.

На современную иранскую литературу оказали влияние Исламская революция и ираноиракская война. Бехруз Шабестари, исследуя остросоциальную иранскую литературу, пишет о произведениях с философским подтекстом, выявляя «новые горизонты, новые художественные темы, литературные формы и художественные стили» (Шабестари, 2012: 54).

Когда К. Аминпур начал писать стихотворения, в Иране уже произошли революция и война. Эти события повлияли решающим образом на его творческий путь, обусловив эволюцию поэтического стиля к свободному стиху.

\section{М. Яхьяпур}

Тегеран университеті, Иран

E-mail: myahya@ut.ac.ir

\section{АЛЕКСАНДР ТВАРДОВСКИЙ МЕН КЕЙСАР АМИНПУРДІН ПОЭЗИЯСЫНДАҒЫ ПАТРИОТТЫҚ ЖӘНЕ БАТЫРЛЫК САРЫНДАР}


Андатпа. Әдеби байланыс және оның өзара іс-әрекеті әлемдік әдеби үрдісте тікелей де, жанама түрде де көрініс табады. Бұл мақала атақты орыс ақыны, Ұлы Отан соғысының қатысушысы, «Жаңа әлем» («Новый мир») әдеби журналының бас редакторы Александр Твардовскийдің және танымал қазіргі заманғы ирандық ақын Кейсар Аминпурдің поэтикалық шығармашылығындағы әдеби параллельге арналған. Соғыс пен бейбітшілік мәселелері - ұлттық әдебиеттің бірнеше ғасырлар бойы келе жатқан мәңгілік проблемалары. Олар орыс ақынының өмірі мен тағдырында және шығармашылығында көрініс табады. Және де К. Аминпурдің поэзиясында да жетекші болып табылады. Отанға деген сағыныш және жер бетіндегі әскери іс-қимылдар тоқтатылып, бейбітшілік орнаса деген арман - А. Твардовский мен К. Аминпурдің поэзиясындағы ортақ концептілер. Адамдар тағдыры оқиғалар иіріміне тартылған, бірақ бейбітшілік үшін күресу қажет. Орыс және ирандық ақын шығармаларындағы патриоттық және батырлық сарындар және оларды бейнелеу тәсілдерінде, шығарма стилі, тілі, композициясында айырмашылық бар, және олар XX ғасырдағы КСРО және XX ғасырдың соңғы ширегі мен XXI ғасырдың бірінші онжылдығындағы Ирандағы әдеби процестің дамуының ерекшелігімен байланыстырылған. Сонымен қатар, ортақтық та бар, ол жалпы А. Твардовский мен К. Аминпурдің поэтикалық шығармашылығын салыстыруға мүмкіндік береді. Патриотизм мен батырлық сарындар табиғат тақырыбы аясында талданады. Отан концептісі мен кіші Отан пейзаждары поэзияда - біртұтас.

Кілт сөздер: патриоттық лирика, көркем аударма, батырлық, мәдениет, сарын, стиль, поэма, пейзаж, эпитет, метафора.

\author{
M. Yahyapur \\ Tehran University, Iran \\ E-mail: myahya@ut.ac.ir
}

\title{
PATRIOTIC AND HEROIC MOTIVES IN THE POETRY OF ALEXANDR TVARDOVSKY AND KEYSAR AMINPUR
}

\begin{abstract}
Connections and interrelations come up in the global literary process directly and indirectly. The present article is devoted to the literary parallels in the creative work of the famous Russian poet, a participant of the Second World War, chief editor of the literary magazine «Nowy Mir» Alexandr Tvardovsky and the popular Iran poet Keysar Aminpur. War and peace problems are persistent in any national literature throughout the centuries. These problems have reflected in the life, fate and creative work of the Russian poet. They are also predominant in the poetry of K. Aminpur. Longing for home, dreams about piece in the world during ongoing military actions- are common concepts in the poetry of Tvardovsky and Aminpur, where people striving for peace have been drawn into the conflict. Patriotic and heroic motives in the poetry of the Russian and the Iran poets, ways of reflection in style, language and composition of the poems are different due to literary process particularities in the USSR and Iran in the last quarter of the XX-th century.

At the same time, there are common points allowing us to compare poetry of A. Tvardovsky and K. Aminpur. Motives of patriotism and heroics are being analyzed from the prospective of nature. Homeland and smaller motherland landscape concepts are inseparable in the poetry of the both poets.
\end{abstract}

Key words: patriotic lirics, literary translation, heroics, culture, motive, style, poem, landscape, epithet, metaphor.

Information about authors:

M. Яхьяпур, Тегеранский университет, Иран. E-mail: myahya@ut.ac.ir. ORCID iD: 0000-0001-8195-6909

\section{ЛИТЕРАТУРА}

[1] Аминпур К. Утреннее дыхание. - Тегеран: Соруш, 1990 (фарси).

[2]. Аминпур К. По словам ласточки. - Тегеран: Хозе хонари, 1996 (фарси). 
[3]. Ананьева С. «Навылет Родина сквозит...». Поэтический образ России в творчестве Валерия Михайлова. Лингвориторическая парадигма: теоретические и прикладные аспекты (РИНЦ), 2015. - 20. - С. 63-68 (рус.).

[4]. Afanasyeva A., Zhaksylykov A., Sarsekeeva N. Типология архетипа дом на примере современной прозы. // The Social Sciences (Scopus). - 2016. - 11. - С. 688-697 (англ.).

[5]. Бердяева О.С. Лирика А. Твардовского. - Москва: Вологда, 1989 (рус.).

[6]. Бралина С.Ж. Текстология и теория фольклорного текста. // Известия НАН РК. Серия филологическая. - 2007. - 4. - С. 3-6 (pyc.).

[7]. Квантре В.Б. Тема отчуждения в творчестве писателей-третьей волны эмиграции. // VII International Symposium. Literature in Exile. Emigrants' Fiction (20 th centure experience) (93-101). Тбилиси, Грузия: Institute of Literature Press, 2013. - C. 93-101.

[8]. Кормилов С.И. История русской литературы ХХ века. - Москва: МГУ, 1998 (рус.).

[9]. Салахшур Я. Изучение поэзии Кейсара Аминпура. - Тегеран: Хозе Хонари, 2010 (рус.).

[10]. Смирнова С.С. Теория автора как проблема. Литературоведение как проблема. // Труды Научного совета «Наука о литературе в контексте наук о культуре» (376-392). Москва, Россия: Наследие, 2001. - С. 376-192.

[11]. Тари М. От войны до мира в стихах Анны Ахматовой и Кейсара Аминпура Отечественная словесность о войне. Проблема национального сознания (К 70-летию Победы в Великой Отечественной войне: Материалы ХХ Шешуковских чтений) (376-383). - Москва, Россия: МГПУ, 2015.

[12]. Твардовский А. Стихи разных лет. - Москва: АСТ, 2003 (рус.).

[13]. Хализев В.Е. Теория литературы. - Москва: Высшая школа, 1999 (рус.).

[14]. Шабестари Б. Влияние ирано-иракской войны на современную новеллистику Ирана. // Караван. - 2012. - 8. - С. 54-59 (pyc.).

[15]. Яхьяпур М., Карими-Мотаххар Д., Мохаммади Ф. Категории времени и пространства в лирике А.А. Ахматовой и С. Сепехри. // Вестник НГУ. Серия: История, филология (РИНЦ). - 2012. - Том 11. Вып. 2. - С.179-187.

\section{ӘДЕБИЕТ}

[1]. Аминпур К. Таңғы тыныс. - Тегеран: Соруш, 1990 (парсы).

[2]. Аминпур К. Қарлығаштың сөзімен. -Тегеран: Хозе хонари, 1996 (парсы).

[3]. Ананьева С. «Навылет Родина сквозит...». Валерий Михайловтың шығармашылығындағы Ресейдің поэтикалық бейнесі. Лингвориторикалық парадигма: теориялық және қолданбалыаспектілері (РИНЦ), 2015. - 20. - 63-68 б. (орыс.).

[4]. Afanasyeva A., Zhaksylykov A., Sarsekeeva N. Қазіргі проза үлгісіндегі үй архетипінің типологиясы. // The Social Sciences (Scopus). - 2016. - 11. - 688-697 б. (ағыл.).

[5]. Бердяева О.С. А. Твардовский лирикасы. - Мәскеу: Вологда, 1989 (орыс.).

[6]. Бралина С.Ж. Фольклорлық мәтіннің текстологиясы ментеориясы. // ҚР ҰҒА Хабаршысы. Филология сериясы. - 2007. 4. - 3-6 б. (орыс.).

[7]. Квантре В.Б. Эмиграцияның үшінші толқын ақын-жазушыларының шығармаларындағы жатсыну тақырыбы. VII International Symposium. Literature in Exile. Emigrants Fiction $\left(20^{\text {th }}\right.$ centure experience) (93-101). Тбилиси, Грузия: Institute of Literature Press, 2013. - 93-101 б.

[8]. КормиловС.И. ХХ ғасырдағы орыс әдебиетінің тарихы. - Мәскеу: МГУ, 1998 (орыс.).

[9]. Салахшур Я. Кейсар Аминпурдің поэзиясын зерттеу. - Тегеран: Хозе Хонари, 2010 (рус.).

[10]. Смирнова С.С. Автордың теориясы проблема ретінде. Әдебиеттану проблема ретінде. «Әдебиет туралы ғылым мәдениет туралы ғылымның мәнмәтінінде» ғылыми кеңестің еңбектері (376-392). // Мәскеу, Ресей: Наследие. - 2001. - 376392.

[11]. Тари М. Соғыстан бейбітшіліккеАнна Ахматова мен Кейсар Аминпурдің өлеңдерінде Отечественная словесность о войне. Проблема национального сознания (К 70-летию Победы в Великой Отечественной войне: Материалы ХX Шешуковских чтений) (376-383). // Мәскеу, Ресей: МГПУ. - 376-383 б.

[12]. Твардовский А. Әр жылдар өлеңдері. - Мәскеу: АСТ, 2003 (орыс.).

[13]. Хализев В.Е. Әдебиет теориясы. - Мәскеу: Высшая школа, 1999 (орыс.).

[14]. Шабестари Б. Қазіргі Иран новеллистикасына иран-ираксоғысының әсері. // Караван. - 2012. - 8. - 54-59 б. (рус.).

[15]. Яхьяпур М., Карими-Мотаххар Д., Мохаммади Ф. А.А. Ахматова мен С. Сепехридің лирикасындағы уақыт және кеңістік категориясы. // НГУ Хабаршысы.Серия: тарих, филология (РИНЦ). - 2012. - Том 11. Шығ. 2. - 179-187 б.

\section{REFERENCES}

[1]. Aminpur K. (1990). Morning breathe. Tehran: SORUSH (farsi).

[2]. Aminpur K. (1996). As swallow said. Tehran: Hoze Honary, 1996 (farsi).

[3]. Ananyeva S. (2015). «Motherland shines through». Poetic image of Russia in the creative work of Valery Mikhailov. Linguarhetorical paradigm: Theoretical and applied aspects (РИНЦ), 20, 63-68 (rus.).

[4]. Afanasyeva A.,Zhaksylykov A.,Sarsekeeva N. (2016). Typology of the Archetype of the House in Samples of Modern Prose. The Social Sciences (Scopus), 11, 688-697 (eng.).

[5]. Berdyaeva O.S. (1989). A. Tvardovsky lirics. Moscow: Vologda (rus.).

[6]. Bralina S.J. (2007). Textology and theory of folklore text. Izvestiya. National Academy of Science RK. Philological series. 4, 3-6 (rus.).

[7]. Kvantre V.B. (2013). Subtraction theme in the creative work of the emigrant writers of the third wave emigration. VII International Symposium. Literature in Exile. Emigrants' Fiction $\left(20^{\text {th }}\right.$ centure experience) (93-101). Tbilisi, Georgia: Institute of Literature Press.

[8]. Kormilov S.I. (1998). History of Russian literature of XX century. Moscow: MSU. (rus.).

[9]. Slakhshur Y. (2010). Studying poetry of Keysar Aminpur. Tehran: Hoze Honary, (rus.).

[10]. Smirnova S.S. (2001). Theory of author as a problem. Literary study as a problem. Works of the scientific group «Science about literature in context of culture sciences» (376-392). Moscow, Russia: Heritage. 
[11]. Tari M. From the war to the piece in the poems of Anna Akhmatova and Keysar Aminpur (2015). National lore about war. Problems of national consciousness (Devoted to the $70^{\text {th }}$ anniversary after the Second World War: Materials of XX Shevkunov readings) (376-383). Moscow, Russia: MNPU.

[12]. Tvardovsky A. (2003). Poems of various years. Moscow: ACT (rus.).

[13]. Khalizeev V.E. (1999). Theory of literature. Moscow: Vysshaya shkola (rus.).

[14]. Shabestary B. (2012). Impact of Iran-Iraq war on the contemporary novelistic of Iran. Karawan. 8, 54-59 (rus.).

[15]. Yahyapur M., Karimi-Motakhar D., Mokhamadi F. (2012). Categories of time and space in the lyric of A.A. Akhmatova and S. Sepekhri. NSU Vestnik. Series: History, philology (РИНЦ). Volume 11. Issue. 2. 179-187. 